\author{
Александра Вранеш \\ Универзитет у Београду \\ Филолошки факултет
}

UDC: 009:001

UDC: 007:004

DOI: 10.18485/dh.2015.1.ch5

\title{
МАНИФЕСТИ ДИГИТАЛНЕ ХУМАНИСТИКЕ ${ }^{1}$
}

\section{Сажетак}

Како у свим наукама, тако и у уметности уопште ослонац је на текстуалној, аудио или визуелној информацији, претраживој у потпу-ности без временских и просторних ограничења, на основу упита који више нису аутор или наслов, већ кључне речи. Не само истраживачким и образовним, већ и комерцијалним аспектом влада сада дигитална хуманистика. У Епштајновом манифесту Трансформативна хуманистика у закључним разматрањима препоручује се формирање Центра за иновације у хуманистици (Center for Hummanities Innovation - СНI) са циљем „да развија потпуно нове гране хуманистике способне да се ухвате у коштац са брзом променљивошћу интелектуалне климе 21. века и нарочито са научним и технолошким напретком.“ У том смислу, Епштајн дефинише међу задацима Центра и следећа два: „да истражи како нове информационе технологије радикално мењају, пркосећи и подстичући, професију хуманисте, традиционални концепт текста и знања, методе превођења, и етику академске заједнице; да развије нови електронски портал InteLnet за интелектуалне иновације, што би омогућило акумулацију и циркулацију нових идеја у хуманистици и трансхуманистици." Хуманистика, која је, како каже Сандер Гилман, „оклеветана, недовољно финансирана, напуштена, све чешће виђена као ирелевантна“ у Епштајновој визији наново је окренута човеку. Дигитална хуманистика, следствено томе, наглашава Џефри Перл, омогућава напуштање концепта самосажаљења и развијање инвентивности. Епштајним и другим актуелним визијама дигиталне хуманистике бави се овај рад.

Кључне речи: Дигитална хуманистика, дигитализација, хуманистика, манифести.

Подручја у којима се пракса појединих научних и уметничких дисциплина прожима са компјутеризацијом (Schreibman, Siemens,

1 Овај текст је скраћена, измењена и допуњена верзија текста Дигитална хуманистика (Дигитална хуманистика и савремене библиотеке / Александра Вранеш // Инфотека. ISSN 1450-9687. Год. 15, бр. 1 (2014), str. 4-15.) 
Unsworth, XXIV) отварају пут дигиталној хуманистици. Дигитална хуманистика је, према Ен Бардик, Јохани Дракер и Питеру Луненфелду, заправо колективни сингулар, настао као производ изазова и споне између појма дигитални и појма хуманистика. Науке попут библиотекарства, библиотечке информатике, рачунарске лингвистике, или дигиталне хуманистике, које имају поуздану емпиријску или технолошку основу, дуго задржавају статус помоћних научних дисциплина, уз непрекидно доказивање аутохтоне терминологије и методолошких посебности. Прелазак на термин „дигитална хуманистика" указује да се ова област уздигла са не баш тако престижног положаја помоћне услуге до једног истински интелектуалног подухвата са сопственим професионалним поступцима, ригорозним стандардима и узбудљивим теоретским истраживањима (Hayles 2011). Сама дигитална хуманистика започела је као „рачунарство у хуманистичким наукама”, или „хуманистичко рачунарство”, и у првим данима је њена улога врло често схватана као техничка подршка раду „правих" хуманиста који су водили главну реч на пројектима. Може се рећи да се оваквом применом рачунара у хуманистичким дисциплинама, „ефикасност машине” није постављала у директно пропорционалан однос са успехом критике (McCarty 2009). И мада ово може звучати иронично, како су пројекти постајали већи, сложенији, и развијали рачунарске технике као суштински део истраживачког процеса, технички образовани истраживачи су све више схватали рачунаре као саставног и незаобилазног чиниоца истраживања у хуманистичким наукама. Шнап и Презнер су у Манифесту дигиталне хуманистике (Digital Humanities Manifesto 2.0) објаснили да је ” први талас рада у дигиталној хуманистици био (...) квантитативан. Мобилисао је могућности база података за претраживање, аутоматизовао корпусну лингвистику, слагао хиперкартице у критичке низове. Други талас је квалитативан, интерпретативан, емпиријски, емоционалан. Он дигиталне комплете алата ставља у службу основних методолошких предности хуманистичких наука: обраћања пажње на сложеност, специфичност медијума, историјски контекст, аналитичку дубину, критику и тумачење. Први талас дигиталних хуманистичких наука крајем деведесетих година прошлог века и почетком 21. века био је превасходно усредсређен на велике пројекте дигитализације 
и успостављање технолошке инфраструктуре, док је садашњи други талас дигиталне хуманистике, који се може назвати „дигитална хуманистика 2.0", дубоко генеративан." (Schnapp and Presner 2009) Електронска књижевност (e-lit), интерактивна фикција (IF), веб-артефакти, твитер, друштвени медији, смс романи, само су неки од производа на чији се настанак и анализу може применити методологија дигиталне хуманистике. Лака доступност дигиталног материјала, лакоћа истраживања, лак осећај напретка стварају од света дигиталне хуманистике паралелну стварност. У њој, међутим, паралелно опстају и сумње: сумње у непрецизност, непоузданост и пролазност присуства дигиталних текстова; у институционалну утемељеност научне комуникације, у којој се често позивамо на мултикултуралност, мултилингвалност, интердисциплинарност, колаборативност, а да заправо у нашој научној методологији ништа нисмо променили. Од почетка настанка дигиталне хуманистике вођени смо једним циљем: заштитити, сачувати и учинити доступним у електронској форми што више културне баштине света. Док се предности дигитализације на пољу коришћења најубедљивије препознају, на пољу чувања су испод оних које везујемо за такозване традиционалне медије. Њихове особине да, уколико су без комерцијалних ограничења, обезбеђују апсолутну доступност, независну од времена и простора, као и максималну заштиту од хабања при директном контакту корисника са драгоценим материјалом, не могу у потпуности да надвладају замерке које се изводе из често високих трошкова везаних за опрему, радну снагу, као и за њихову кратковекост из више разлога, али и за велика улагања и напоре уколико њихов животни век желимо да учинимо што трајнијим. Отуда Luhterhand скептично закључује да су дигитални медији „веома велики луксуз“, јер „све оno о с̌еmu se ne brinete redovno, jednog dana više neće biti raspoloživo“2.

Могли бисмо да кажемо да трећи талас дигиталне хуманистике показује начин на који дигитална технологија истиче аномалије

2 Овакав заључак Luhterhand извлачи из чињенице да се може догодити да данас скенирани документ не буде читљив кроз 20 година због промене софтверских и хардверских решења. Хибридно микрофилмовање, које омогућава дигитализацију садржаја микрофилма, а не самог документа, тако постаје пожељан поступак заштите документације за многе установе које чувају културну баштину, јер као коначне производе обезбеђује и микрофилм и дигитални запис. 
које настају у неком истраживачком пројекту у хуманистичким наукама и води до преиспитивања претпоставки имплицитних у таквом истраживању, као што су нпр. критичко читање, стварање канона, периодизација, либерални хуманизам итд. Ми смо, како каже Презнер у свом манифесту (2010: 10) „на почетку промене стандарда којима се руководе прихватљиви проблеми, концепти и објашњења, а такође и усред трансформације институционалних и концептуалних предуслова за стварање, преношење, доступност, и очување знања." Данас већ полако улазимо у фазу у којој треба да почнемо да размишљамо и како да обришемо или заборавимо оно што нам је мање или никако потребно.

Захваљујући Организацији Уједињених Нација за образовање, науку и културу, културна баштина се истиче као незаобилазан фактор глобализације и залог међунационалних дијалога, а употреба нових информационих и комуникационих технологија, којима се она чува и промовише, треба да допринесе афирмисању и достизању (EFA Education for All) циљева. Дигитализацијом се обезбеђују чување и промоција документарно-историјске, културне и научне баштине, доприноси се развоју демократичности знања и омогућава учење на даљину. Мало је битно да ли је изабрани медиј глас, тело, одштампана страница, или пикселизирани објекат. Све тековине, садашње и претходне изложене су оштром просуђивању, било да су умерене или скандалозне, херојске или глупе, приватне или јавне. Замагљена је и линија између између критичара и доносиоца одлука, научника и забављача. У Епштајновом манифесту «време је кратко, ово је жанр у журби.» Стваралац се упозорава да "ако очекује линеарност и логику или академску доследност, греши, јер жанр има једину логику: M's: mix :: match :: mash :: manifest, односно: не кукај; коментариши, ангажуј се, разгласи идеју; придружи се; иди даље.» Дигитална хуманистика није јединствено поље, већ низ конвергентних пракси које истражују свемир у којима:

а) штампање више није искључиво нормативни медиј којим се знање производи и / или дистрибуира; штампа се апсорбује у нове, мултимедијалне конфигурације;

б) дигитални алати, технике и медији мењају производњу и ширење знања у уметности, хуманистичким и друштвеним наукама. 
Дигиталне хуманистичке науке настоји да играју инаугуралну улогу у односу на свет у којем више нико није једини произвођач, управитељ и дисеминатор знања или културе. Универзитети се позивају да обликују изворно дигиталне моделе (веб, блогосфере, дигиталне библиотеке, итд) и иновације у овим областима и да олакшају формирање мреже за производњу, размену и ширење знања, који су, одједном, и глобални и локални. Универзитет у Мелбурну оформио је 2011. године Удружење истраживача дигиталне хуманистике, указујући на потребу да се поменута синтагма користи у истом значењу у Аустралији, као у Европи и Америци, не подразумевајући под њом само дигитални факсимил, већ интерпретативни, машински читљив текст.

Штампани модел су апсорбовали други хибридни модели комуникације, који су наметнули промене у језику, пракси, методологији, а оне резултирају интердисциплинарношћу и мултидисциплинарношћу. Отвореност извора и приступа је једина законитост. Дигитална хуманистика, заправо, означава: музеје, библиотеке, архиве, галерије - без зидова; демократизацију знања и културе; укидање граница између природних и друштвених наука; интелектуалн креативност; микс медија; некад и дигиталну анархију и вредновање креативне копије колико и оригинала. Генеративна хуманистика, као њен највиши облик, подразумева: надограђивање веће слике над експертским знањем; сарадњу и креативност; трансверзално, трансдисциплинарно, иновативно размишљање; тимски рад; процес, а не производ; омасовљење знања, ван универзитета.

Према постојећим манифестима, а нису малобројни, јер и институције и појединци имају потребу за канонизацијом, у овом случају недосегнутом, све се то постиже: проширењем квалитета, домета и утицаја знања у хуманистичким наукама; ангажовањем у дизајну и развојним процесима који доводе до богатијих, вишесмерних модела, жанрова, академске комуникације и праксе. Традиционална хуманистика је "балканизована“ језиком, нацијом, методологијом, медијем. Дигитална хуманистика је конвергенција не само међу хуманистичким дисциплинама, већ и између уметности, науке и технологије, којој су основне особине: радозналост, отворе- 
ност, укрштање истраживања, примена нових методологија, слобода у коришћењу ауторских права, креативност, храброст, визионарство, слобода располагања садржајима, педагошка домишљатост.

Суочавајући се са изазовима образовања, свака дигитална колекција доприноси ширењу информационе писмености и опште просвећености, дигиталној заштити, чувањуи коришћењудокументарноисторијске, културне и научне баштине. На том путу поједини продукти затвараће поступно неке наше ситне, или крупне, али свакако слободе на које смо се претходно навикли. „Дигиталне технологије нису више“, каже Чарли Гир, „само обичне алатке, већ, било то добро или лоше, све више учесници у нашој све више партиципаторној култури." Стога се они не спутавају правилима, прописима, кодовима, вредностима и принципима, већ се у својим истраживањима руководе креативношћу, критичношћу, динамичношћу, слободом мишљења. У дигиталној хуманистици језик постаје све значајније потреба, идентификација и дивергенција и зато свако истраживање у области дигиталне културе мора да почне и заврши питањима присуства условно мањих језичких заједница. Формирајући дигиталну збирку наше хуманистике, враћамо дуг њеним творцима, претходним генерацијама, и задужујемо следеће које ваља да наставе да чувају наш културолошки, духовни и национални идентитет.

\section{Библиографија}

Baker, N. (1996) The Size of Thoughts: Essays and Other Lumber, New York: Random House.

Baker, N. (2001) Double Fold: Libraries and the Assault on Paper, New York: Random House.

Berry, D. M. (2011) The Philosophy of Software: Code and Mediation in the Digital Age, London: Palgrave Macmillan.

Clinamen (2011) The Procedural Rhetorics of the Obama Campaign, retrieved 15/1/2011 from http://clinamen.jamesjbrownjr.net/2011/01/15/the-procedural-rhetoricsof-the-obama-campaign/

Flanders, J. (2009) The Productive Unease of 21st-century Digital Scholarship, Digital Humanities Quarterly, Summer 2009, Volume 3 Number 3, retrieved 10/10/2010 from http://digitalhumanities.org/dhq/vol/3/3/000055/000055.html 
Fuller, M. (2008) Software Studies \A Lexicon, London: MIT Press.

Fuller, S. (2010) Humanity: The Always Already - or Never to be - Object of the Social Sciences?, in Bouwel, J. W. (ed.) The Social Sciences and Democracy, London: Palgrave.

Hayles, N. K. (2011) How We Think: Transforming Power and Digital Technologies, in Berry, D. M. (ed.) Understanding the Digital Humanities, London: Palgrave.

JAH (2008) Interchange: The Promise of Digital History, The Journal of American History, retrieved 12/12/2010 from http://www.journalofamericanhistory.org/ issues/952/interchange/index.html

Lakatos, I. (1980) Methodology of Scientific Research Programmes, Cambridge: Cambridge University Press.

Liu. A. (2003) The Humanities: A Technical Profession, retrieved 15/12/2010 from http:// www.english.ucsb.edu/faculty/ayliu/research/talks/2003mla/liu_talk.pdf

Liu, A. (2011) Where is Cultural Criticism in the Digital Humanities, retrieved 15/1/2011 from http://liu.english.ucsb.edu/where-is-cultural-criticism-in-the-digital-humanities/

Manovich, L. (2008) Software Takes Commons, retrieved 1/12/2010 from http://lab. softwarestudies.com/2008/11/softbook.html

McCarty, W. (2009) Attending from and to the machine, retrieved 18/09/2010 from http://staff.cch.kcl.ac.uk/ wmccarty/essays/McCarty,\%20Inaugural.pdf

Montfort, Nick. (2004) Continuous Paper: The Early Materiality and Workings of Electronic Literature, retrieved 16/1/2011 from http://nickm.com/writing/ essays/continuous_paper_mla.html

Montfort, N. and Bogost, I. (2009) Racing the Beam: The Atari Video Computer System, London: MIT Press.

Moretti, F. (2000) Conjectures on World Literature, retrieved 20/10/2010 from http:// www.newleftreview.org/A2094

Moretti, F. (2007) Graphs, Maps, Trees: Abstract Models for a Literary History, London, Verso.

Ramsay, S. (2011) On Building, retrieved 15/1/11 from http://lenz.unl.edu/ wordpress $/ \mathrm{p}=340$

Sample, M. (2011) Criminal Code: The Procedural Logic of Crime in Videogames, retrieved 15/1/2011 from http://www.samplereality.com/2011/01/14/criminal-code-theprocedural-logic-of-crime-in-videogames/

Schnapp, J. and Presner, P. (2009) Digital Humanities Manifesto 2.0, retrieved 14/10/2010 from http://www.humanitiesblast.com/manifesto/Manifesto_V2.pdf

Schreibman, S., Siemans, R., and Unsworth, J. (2008) A Companion to Digital Humanities, London: Wiley-Blackwell. 


\title{
Aleksandra Vraneš \\ University of Belgrade \\ Faculty of Philology
}

\section{DIGITAL HUMANITIES MANIFESTOS}

\begin{abstract}
Summary
As in all the sciences, the reliance in the arts in general is on textual, audio or visual information, entirely searchable with no time and space constraints, based on queries that are no longer the author or title, but the key words. Digital humanities are now prevailing not only in the research and education, but also in the commercial aspect. In Epstein's manifesto The Transformative Humanities, the establishment of the Centre for Humanities Innovation ( $\mathrm{CHI}$ ) is recommended within concluding remarks, with the aim to "develop entirely new branches of the humanities able to cope with the rapid variability of the intellectual climate of the 21st century, and especially with the scientific and technological progress." In this sense, Epstein includes amongst the tasks of the Centre the following two: "to explore how the new information technologies are radically changing, by defying and encouraging the humanist profession, traditional concept of text and knowledge, translation methods, and ethics of the academic community; to develop a new electronic portal InteLnet for intellectual innovations, which would allow the accumulation and circulation of new ideas within the humanities and transhumanities." Humanities, which, as Sander Gilman said, are "slandered, underfunded, abandoned, increasingly seen as irrelevant" are again turned towards man in Epstein's vision. Digital Humanities, consequently, emphasizes Jeffrey Perl, allow abandonment of the concept of self-pity and development of inventiveness. This paper deals with Epstein's and other current visions of digital humanities.
\end{abstract}

Key words: Digital humanities, digitalization, humanities, manifestos 